\title{
MEMBUMIKAN HUKUM ISLAM PROGRESIF: Respons Konsumen Muslim terhadap Undang-Undang Jaminan Produk Halal
}

\author{
Mashudi \\ Universitas Islam Negeri (UIN) Walisongo Semarang Jawa Tengah \\ E-mail:mashudi@walisongo.ac.id
}

\begin{abstract}
The law on the guarantee of halal products authorized by the House of Representatives on 25 September 2014 is a legal umbrella for the Indonesian people about food products, drugs, and cosmetics that have been started for a long time and have been postponed several times. The existence of this law is a progressive law that places humans as the primary object. Furthermore, this provides an opportunity for the role of society (especially Muslim consumers) in promoting and educating halal products. The law on the guarantee of halal products born through law is the "ijtihad" (private examination of Islamic law) through which living law in society becomes the source of national law concerning food products, medicines, and cosmetics. Efforts to legal ground is through various models such as promoting it to the parties through law enforcement, realizing halal as a culture of life, etc.
\end{abstract}

Key words: Grounding; Halal Product Guarantee; Progressive Islamic Law

\begin{abstract}
ABSTRAK
Undang-undang tentang jaminan produk halal yang disahkan oleh DPR RI pada tanggal 25 September 2014 merupakan payung hukum bagi masyarakat Indonesia tentang produk makanan, obat-obatan terlarang, dan kosmetik yang telah dimulai sejak lama dan telah beberapa kali mengalami penundaan. Keberadaan undang-undang ini merupakan hukum progresif yang menempatkan manusia sebagai objek utama. Lebih jauh lagi, ini memberi kesempatan bagi peran masyarakat (terutama konsumen Muslim) dalam mempromosikan dan mendidik produk halal.
\end{abstract}


Hukum tentang Jaminan produk halal yang lahir melalui undang-undang merupakan "ijtihad" (ujian pribadi tentang hukum Islam) yang melaluinya hukum hidup di masyarakat menjadi sumber hukum nasional mengenai produk makanan, obat-obatan, dan kosmetik. Upaya membumikan hukumnya adalah melalui berbagai model seperti mempromosikannya kepada para pihak melalui penegakan hukum, mewujudkan halal sebagai budaya kehidupan, dll.

Kata kunci: Hukum Islam Progresif; Jaminan Produk Halal; Membumikan

\section{A. Pendahuluan}

Keberadaan Indonesia sebagai negara hukum (weltanschaaung) sebagaimana tercantum dalam UUD 1945 mengamanatkan agar gerak langkah kehidupan dan lalu lintas kegiatan berbangsa dan bernegara bermuara pada hukum. Berbagai Rencana Undang-Undang yang menyangkut hajat hidup orang banyak menumpuk di DPR dan belum jelas kapan akan diputuskan menjadi Undang-undang. Faktor utama yang menyebabkan lambatnya RUU disahkan menjadi UU adalah kuatnya tarikan kepentingan baik yang bersifat institusional, fungsional, maupun pragmatisme. Kondisi tersebut memperkuat opini bahwa hukum merupakan produk politik dan kehadirannya hasil tarik menarik kepentingan secara politis.

Wajah hukum produk halal "tercoreng" oleh para pelaku yang penyalahgunaan Bahan Tambahan Pangan (BTP), penggunaan zat additive secara bebas, pemasangan label halal (RUU Jaminan Produk Halal, 2007: 50-51) tanpa prosedur hukum dan tidak memasang batas akhir masa aktif (daluwarsa). Akibatnya masyarakat dikejutkan dengan kasus sprite, sosis aroma, boraks-formalin, ayam impor-ayam tiren (istilah lain dari ayam mati kemarin) (Thobieb al-Asyhar:22), celeng cap sop, ajinomoto (Thobieb alAsyhar, 2003: 15), hati import, sapi glonggongan, dan lain-lain.

Penyebab utama terjadinya kasus tersebut adalah belum adanya legislasi hukum di Indonesia khusus mengenai Jaminan Produk Halal yang menjadi payung hukum dan bersifat mandatory bukan voluntary.

Tanggal 25 September 2014 masyarakat konsumen merasa "sedikit lega" karena Rencana Undang-Undang Jaminan Produk Halal disahkan DPR RI melalui sidang paripurna menjadi Undang-undang yang sempat 
"mangkrak" (RUU Jaminan Produk Halal ), selama bertahun-tahun. Saat ini masyarakat konsumen berharap agar pasca diundangkan UndangUndang Jaminan Produk Halal segera ditindaklanjuti dengan Peraturan Pemerintah. Kehadirannya dapat memberikan kepastian hukum bagi konsumen, khususnya konsumen muslim terhadap produk makanan dan barang konsumsi lainnya.

Problem rutin segera menyusul adalah mengenai keadilan, kebenaran, dan keberanian hukum yang sering tidak berpihak pada masyarakat, terlebih masyarakat marginal yang kurang beruntung secara politis dan ekonomis. Itulah sebabnya dedikasi, loyalitas, dan komitmen aparat penegak hukum sangat dinantikan masyarakat konsumen. Penegakan hukum dimaksudkan bersifat mutlak, manfaat dan maslahatnya terukur (measurable), progresif dan futuristik bukan regresif sehingga menjadi hukum yang menyejahterakan.

\section{B. Pembahasan}

\section{Kekosongan Hukum Bidang Jaminan Produk Halal}

Konsep negara kesejahteraan (welfare state) (Attmasasmita, 1994: 57) mengidealkan suatu negara berperan besar dalam menjawab kebutuhan masyarakat. Meluasnya campur tangan hukum ke dalam bidang-bidang kehidupan masyarakat menyebabkan perhatian terhadap masalah-masalah sosial menjadi semakin intensif. Meskipun di sisi lain, penetrasi yang semakin luas juga semakin menimbulkan masalah-masalah baru seperti hubungan antara perkembangan masyarakat dengan perkembangan hukumnya. Lebih dari itu, berbagai permasalahan baru yang disebabkan oleh adanya "perkembangan" tersebut, memerlukan suatu pendekatan yang relevan (Suryandaru Utama, 2005: 165).

Ahli Sociological Jurisprudence, Roscoe Pound menegaskan bahwa hukumlah yang seharusnya menjadi instrumen untuk mengarahkan masyarakat menuju sasaran yang hendak dicapai, bahkan hukum digunakan untuk menghilangkan berbagai kebiasaan masyarakat yang bersifat negatif (Satjipto Rahardjo, 1986: 110-111). Dalam praktek pemerintahan di Indonesia konsep law as a tool of social engineering diperkenalkan oleh Mochtar Kusuma Atmadja yang menyatakan bahwa, hukum di Indonesia 
tidak cukup berperan sebagai alat, melainkan juga sebagai sarana pembaharuan masyarakat.

Kenyataannya, pendayagunaan hukum sebagai sarana untuk merekayasa masyarakat menuju skenario kebijakan pemerintah amat terasa diperlukan oleh negara-negara berkembang, jauh melebihi kebutuhan negara-negara industri, karena negara-negara maju telah memiliki mekanisme hukum yang telah "mapan" untuk mengakomodasi perubahan-perubahan di dalam masyarakat, sedangkan negara-negara berkembang tidaklah demikian (Mochtar Kusuma Atmaja, 1994: 231). Indonesia yang mayoritas penduduknya muslim, strategi untuk menangkap dan mengakomodasi perubahan nilai-nilai hukum yang ada di masyarakat dalam rangka mengembangkan skenario bagi kebijakan pemerintah yang tertuang dalam berbagai peraturan perundang-undangan merupakan kebutuhan nyata.

Berbagai peraturan perundang-undangan yang dikeluarkan pemerintah dalam rangka pembangunan sosial ekonomi dengan mendasarkan pada konsep law as tool of social engineering, ternyata belum berhasil mewujudkan tujuan nasional, yakni masyarakat yang adil dan makmur. Memang secara kuantitatif Indonesia dapat mencapai pertumbuhan ekonomi yang tinggi pada waktu-waktu yang lalu, namun secara kualitatif harus dibayar mahal dengan mengorbankan kesejahteraan sebagian masyarakat yang lain, karena pertumbuhan ekonomi yang terjadi bersifat timpang, hanya dinikmati oleh sebagian kecil penduduk yang pada akhirnya menimbulkan berbagai sengketa dan konflik hampir di seluruh wilayah NKRI.

Kekosongan hukum diartikan suatu keadaan kosong (KBBI,1989) atau ketiadaan peraturan perundang-undangan (hukum) yang mengatur tata tertib (tertentu) dalam masyarakat. Sehingga kekosongan hukum dalam Hukum Positif lebih tepat dikatakan sebagai kekosongan undangundang/peraturan perundang-undangan.

Penyusunan peraturan perundang-undangan baik oleh Legislatif maupun Eksekutif, kenyataannya memerlukan waktu yang lama, sehingga pada saat peraturan perundang-undangan dinyatakan berlaku hal-hal atau keadaan yang hendak diatur oleh peraturan tersebut sudah berubah. Selain itu kekosongan hukum dapat terjadi karena hal-hal atau keadaan yang 
terjadi belum diatur dalam suatu peraturan perundang-undangan. Atau, sekalipun telah diatur dalam suatu peraturan perundang-undangan namun tidak jelas (tidak lengkap). Peraturan perundang-undangan yang berlaku pada suatu negara dalam suatu waktu tertentu merupakan suatu sistem formal, yang tidak mudah untuk mengubah atau mencabutnya walaupun sudah tidak sesuai lagi dengan perkembangan masyarakat yang diatur oleh peraturan perundang-undangan tersebut.

Akibat yang ditimbulkan kekosongan hukum Jaminan Produk Halal, terhadap hal-hal atau keadaan yang tidak atau belum diatur, terjadi ketidakpastian hukum (rechtsonzekerheid) atau ketidakpastian peraturan perundang-undangan di masyarakat atau bahkan berakibat pada kekacauan hukum (rechtsverwarring), dalam arti bahwa selama tidak diatur berarti boleh, selama belum ada tata cara yang jelas dan diatur berarti bukan tidak boleh. Hal inilah yang menyebabkan kekacauan dalam masyarakat mengenai aturan apa yang harus dipakai atau diterapkan (Satjipto Rahardjo, 2004: 14).

Penegakan dan penerapan hukum, seringkali menghadapi kendala berkaitan dengan perkembangan masyarakat. Berbagai kasus di bidang produk pangan, obat-obatan dan kosmetika, menggambarkan sulitnya penegak hukum atau aparat hukum mencari cara agar hukum dapat sejalan dengan norma masyarakat yang ada. Bermula dari faktor perkembangan masyarakat lebih cepat dari perkembangan aturan perundang-undangan, sehingga perkembangannya menjadi titik tolak dari keberadaan suatu peraturan. Dalam kehidupan bermasyarakat diperlukan sistem hukum untuk menciptakan kehidupan yang harmonis dan teratur (RUUJaminan Produk Halal: 12). Hukum, dengan sifatnya yang global tidak mencakup seluruh perkara yang ada di masyarakat, begitu pula asas legalitas terkadang juga tidak dapat menghadirkan kepastian hukum oleh karena berdasarkan analisa socio-legal, masyarakat berkembang cukup cepat seiring dengan kemajuan teknologi sehingga adakalanya suatu peraturan perundangundangan tidak jelas atau bahkan tidak lengkap yang berakibat adanya kekosongan hukum di masyarakat.

Kondisi tersebut menjadi ujian fleksibilitas dan elastisitas hukum dalam merespon setiap problem masyarakatnya. Kalau tidak, maka akan selalu timbul kekosongan hukum. Untuk itu sangat diperlukan suatu 
hukum yang stabil dan fleksibel dan mampu mengikuti perkembangan zaman. Salah satu upaya yang dapat dilakukan dalam mengatasi terjadinya kekosongan hukum adalah menemukan hukum. Penemuan hukum dapat dilakukan oleh siapa saja yang penting memiliki kepakaran di bidang hukum, terutama oleh hakim. Penemuan hukum (rechtsvinding) oleh hakim (Pasal 21 A.B., 1847 : 23) untuk mengatasi kekosongan hukum, melalui usaha interpretasi atau penafsiran peraturan perundang-undangan secara positif pada setiap kasus yang terjadi, karena ada kalanya UU tidak jelas, tidak lengkap, atau mungkin sudah tidak relevan dengan zaman (out of date) (Pasal 22 A.B., $1847: 23$ ).

Ikhtiar mengatasi kekosongan hukum di masyarakat sangat diperlukan kebijakan atau prakarsa dari Badan Pembentuk Perundangundangan, yang berdasarkan Undang-Undang Dasar Negara Republik Indonesia Tahun 1945 (UUD 1945 yang telah diamandemen) (UUD '45 Pasal 20). Hal ini berarti prakarsa atau kebijakan (political will) dari DPR dan Pemerintah (Presiden) memegang peranan yang penting dalam menciptakan atau membentuk suatu undang-undang (lebih luas peraturan perundang-undangan) baik mengatur hal-hal atau keadaan yang tidak diatur sebelumnya maupun perubahan atau penyempurnaan dari peraturan perundang-undangan yang telah ada namun sudah tidak sesuai dengan perkembangan di masyarakat. Lebih lanjut dalam upaya mengatasi kekosongan hukum maka harus mendasarkan pada ketentuan yang berlaku (UU No. 10 , 2004).

Kehidupan hukum (Abaduddin Nata: 455) di masa transisi, sangat membutuhkan penafsiran secara bijaksana. Berkaitan dengan itu, pemikiran Profesor Satjipto, begawan hukum progresif, bahwa tipe pertama perubahan (change) sebagai perubahan kebijakan (policy change), dan tipe ini akan lebih banyak menjelaskan mengenai hukum yang berkaitan dengan administrasi kemasyarakatan (social administration law). Sedangkan tipe yang kedua perubahan (change) yang lebih merujuk kepada reformasi hukum (law reform) (Undip, 2005).

Hukum dapat dilihat paling tidak dalam 3 (tiga) fase, yaitu proses, produk dan instrument. Fase proses, yaitu dalam pembuatan dan pelaksanaannya, aturan-aturan hukum sebenarnya sarat dengan pergulatan sosial. Pada taraf pembuatannya terjadi pertarungan ide, nilai, kepentingan, 
dan persaingan kekuatan para perancang dan pembuatnya. Sedangkan pada taraf pelaksanaannya, aturan-aturan hukum itu harus dijalankan oleh aparat penegak hukum. Masing-masing lembaga itu tidak hanya terdiri dari aparaturnya tetapi juga menghadapi masalah-masalah organisasi seperti dana, sarana dan prasarana, kebijakan, manajemen dan lain-lain. Dalam pergumulan itulah aturan-aturan hukum harus dijalankan (RUU Jaminan Produk Halal: 8). Sehingga faktor tersebut memengaruhi fase kedua, yaitu fase produk penegakan hukum. Penerapan metode empiric-nomologis merupakan keharusan dalam mengkaji hukum pada fase ini.

Pada pihak lain, sebagai produk hukum, Undang-Undang Jaminan Produk Halal tampil dalam wujud aturan-aturan normatif yang di dalamnya terdapat perintah, larangan, sanksi, asas, doktrin dan lain-lain yang kesemuanya merupakan gugus normatif yang bersifat harus. Pengkajian terhadap masalah tersebut harus menggunakan metode penelitian hukum normatif. Fase lain adalah hukum sebagai fase instrumen. Pada fase ini, hukum hanyalah alat bagi manusia, dan karenanya melibatkan aspek-aspek manusiawi; keterampilan, kemampuan sumber daya, tujuan, dan sistem situasi. Sebagai teknologi, Undang-Undang Jaminan Produk Halal tunduk pada sistem komunikasi manfaat, komunikasi peskriptif dan doktrinal hukum. Sehingga, penerapan metode non-doktrinal merupakan keharusan (HS. Brojo Sudjono, 2004: 77).

Kendatipun demikian, penegakan hukum (law enforcement) tetap merupakan bagian terpenting dalam memberikan jaminan produk halal kepada masyarakat. Tanpa adanya pengawasan dan penegakan yang kuat, penyalahgunaan wewenang dan pelanggaran hukum oleh produsen semakin tidak terkendali. Adapun cara pengawasan dan penegakannya mendasarkan pada pranata hukum yang ada (Depag RI, 2003: 262).

\section{Menakar Undang-Undang Jaminan Produk Halal sebagai Hukum Progresif.}

Salah satu simpulan penulis terhadap ceramah Prof. Satjipto dalam beberapa pertemuan perkuliahan bahwa hakikat hukum progresif adalah hukum yang berupaya menempatkan manusia sebagai pihak yang terhormat, terhormat karena taat dan patuh pada hukum, terhormat karena pandai menghargai pendapat orang lain, terhormat karena menghargai 
hukum sebagai panglima dalam kehidupan. Sehingga menurut hukum progresif, hukum adalah untuk manusia dan tidak bersikap submisif begitu saja terhadap hukum yang ada, namun tetap bersikap kritis (M. Syamsudin, 2012: 105).

Nilai-nilai luhur Islam dalam Al-Qur'an dan al-Hadits mengenai pangan halal harus dihormati oleh umat beragama sebagai bagian dari hukum pragresif. Dalam kehidupan sehari-hari sebagai warga bangsa hendaknya menyadari ada aspek hukum yang mengatur dan harus mereka patuhi. Tentu saja seberapa besar kesadaran itu, sangat tergantung kepada komposisi besar-kecilnya komunitas umat Islam, seberapa jauh ajaran Islam diyakini dan diterima oleh individu dan masyarakat, dan sejauh mana pula pengaruh dari pranata sosial dan politik dalam memperhatikan pelaksanaan ajaran-ajaran Islam dan hukum-hukumnya dalam kehidupan masyarakat itu (Noor Rohman Fauzan, 2011).

\section{a. Undang-Undang Jaminan Produk Halal dan Kebijakan Pembangunan Hukum}

Setelah merdeka, kita telah memiliki undang-undang dasar, yang kini, oleh Undang-Undang RI Nomor 10 Tahun 2004, diletakkan dalam hirarki tertinggi peraturan perundang-undangan kita. Setelah MPR tidak lagi berwenang mengeluarkan ketetapan, maka semua undang-undang harus mengacu langsung kepada undang-undang dasar. Mahkamah Konstitusi berwenang untuk melakukan uji materil terhadap undangundang dasar. Kalau mahkamah berpendapat bahwa materi pengaturan di dalam undang-undang bertentangan dengan pasal-pasal tertentu di dalam undang-undang dasar, maka undang-undang itu dapat dibatalkan dan dinyatakan tidak berlaku, baik sebagian maupun seluruhnya.

Dilihat dari sudut teori ilmu hukum, Undang-Undang Jaminan Produk Halal adalah sumber hukum di bidang produk halal. Artinya undang-undang itu adalah sumber dalam kita menggali hukum dalam merumuskan kaidah-kaidah hukum positif, dalam hal ini undang-undang di bidang produk pangan, obat-obatan dan kosmetika. Sudah barangtentu undang-undang dasar semata, tidaklah selalu dapat dijadikan sebagai sumber hukum dalam merumuskan norma hukukm positif, mengingat sifat terbatas dari pengaturan di dalam undang-undang dasar itu sendiri. Undang-undang Dasar adalah hukum dasar yang tertulis, yang pada 
umumnya memuat aturan-aturan dasar dalam penyelenggaran negara, kehidupan sosial dan ekonomi, termasuk jaminan hak-hak asasi manusia dan hak asasi warga negara. Di samping undang-undang dasar terdapat hukum dasar yang tidak tertulis, yakni berbagai konvensi yang tumbuh dan terpelihara di dalam praktik penyelenggaraan negara. Dalam merumuskan kaidah-kaidah hukum positif di bidang hukum tata negara dan administrasi negara khususnya, bukan hanya hukum dasar yang tertulis yang dijadikan rujukan, tetapi juga hukum dasar yang tidak tertulis itu.

Dalam merumuskan kaidah-kaidah hukum positif lainnya, para perumus kaidah-kaidah hukum positif harus pula merujuk pada faktorfaktor filosofis bernegara kita, jiwa dan semangat bangsa kita, komposisi kemajemukan bangsa kita, kesadaran hukum masyarakat, dan kaidahkaidah hukum yang hidup, tumbuh dan berkembang di tengah-tengah masyarakat. Sebab itulah, dalam merumuskan kaidah hukum postif, kita tidak boleh bertindak sembarangan, oleh karena jika kaidah-kaidah yang kita rumuskan itu bertentangan dengan apa yang saya sebutkan ini, maka kaidah hukum yang kita rumuskan itu sukar untuk dilaksanakan di dalam praktik. Unsur-unsur filosofis bernegara kita, jiwa dan semangat bangsa kita, komposisi kemajemukan bangsa kita (Pembukaan UUD '45).

\section{b. Undang-Undang Jaminan Produk Halal sebagai Terobosan Hukum}

Banyak kritik yang dilontarkan publik atas disahkannya UndangUndang Jaminan Produk Halal yang dianggapnya tidak adil, monopoli dan tidak tepat sasaran. Sementara di satu sisi DPR sudah berusaha keras mengerahkan segenap kemampuannya untuk memproduksi putusan yang memenuhi rasa keadilan bagi para pihak pencari keadilan (justiciabellen). Tapi tetap saja kritik yang kadang bahkan penuh dengan prejudice dan apriori selalu mengemuka. Padahal bisa jadi persepsi publik tentang makna keadilan itu berbeda antara satu dan yang lainnya (Hasanuddin, 2007).

Para ahli berbeda pendapat mengenai definisi keadilan, Lord Denning, seorang Hakim Agung Inggris, misalnya mengatakan bahwa Justice is not something you can see. It is not temporal but eternal. How does a man know what is justice. It is not the product of his intellect but of his spirit. Masalahnya adalah hukum dan keadilan tidak selalu berjalan linear. Karena, tidak selamanya yang legal itu justice dan tidak selamanya 
yang lawfull (sesuai dengan hukum) itu juga justice. Itulah sebabanya Rifyal Ka'bah memperkenalkan tiga bentuk keadilan, yakni : Legal Justice, Moral Justice dan Social Justice.

Idealnya, sebuah putusan harus mencerminkan tiga bentuk keadilan tersebut, yakni keadilan hukum negara yang merepresentasikan keadilan moral dan keadilan sosial yang ada dalam masyarakat. Akan tetapi problematika berikutnya adalah metode untuk menyelaraskan tiga bentuk justice itu dalam sebuah putusan memang memerlukan ketelitian sehingga sulit sekali diwujudkan terutama dalam perkara perdata. Adapun faktor penyebabnya adalah : untuk mencapai kebenaran formal dan mengutamakan penerapan ketentuan undang-undang (Statute law must prevail) (Satjipto Rahardjo, 2009: 5).

Padahal dari 3 (tiga) aliran teori hukum: (1) aliran legisme atau legal positivism. Hakim berperan hanya melakukan pelaksanaan UU (wetstoepassing), (2) aliran Freie Rechtsbewegung. Hakim bertugas untuk menciptakan hukum (Rechtsschepping) dan sama sekali tidak terikat UU, dan (3) Aliran Rechtsvinding. Hakim mempunyai kebebasan yang terikat atau keterikatan yang bebas, Indonesia harus mempertegas dirinya dengan mengikuti aliran Rechtsvinding/Legal Realisme plus. Sistem hukum kebiasaan plus tuntutan keadilan (Bustanul Arifin, 1998: 37 dan Qodri Azizy, 1997: 18).

Adapun upaya penyelarasan keadilan berdasarkan moralitas dan budaya hukum di satu pihak dengan keadilan hukum yang diterapkan oleh Negara di pihak lain dapat ditempuh melalui revisi peraturan perundangundangan yang ada dan penyempurnaan system keadilan berdasarkan gagasan-gagasan dan rasa keadilan yang hidup dalam masyarakat.

Manfaat lain dari pembahasan mengenai produk halal sebagai hubungan hukum adalah pembangunan ekonomi, keberhasilan pembangunan ekonomi sangat berkait dengan pembaharuan hukum. Membangun dan memperkuat institusi-institusi hukum (Satjipto Rahardjo:167) berarti "precondition for economic change", "crucial to the viability of new political system", and "an agent of social change". Namun agar hukum berperan dalam pembangunan ekonomi nasional maka hukum hendaknya memenuhi lima kualitas, yaitu: kepastian (predictability), stabilitas (stability), keadilan (fairness), pendidikan (education), dan 
kemampuan SDM di bidang hukum (special abilities of the lawyer) (Satjipto Rahardjo: 86-93).

Kebutuhan konsumen muslim terhadap kepastian fungsi hukum Jaminan Produk Halal besar sekali, khususnya bagi Indonesia dimana sebagian besar rakyatnya baru pertama kali memasuki hubunganhubungan ekonomi melampaui lingkungan sosial yang tradisional. Hukum Jaminan Produk Halal harus dapat menjamin investasi asing, bagaimana penyelesaian yang adil dan jaminan hukum terhadap hasil yang mereka peroleh.

Stabilitas pelaksanaan hukum Jaminan Produk Halal adalah potensi hukum menyeimbangkan dan mengakomodasi nilai-nilai atau kepentingan-kepentingan yang saling bersaing dalam masyarakat sehingga akan berdampak timbulnya stabilitas. Oleh karena itu pemenuhan akan kebutuhan perundang-undangan yang mentranformasikan nilai-nilai syariah sebagai konsekuensi dari tumbuhnya kesadaran beragama dari masyarakat untuk melaksanakan ajaran agamanya menjadi faktor penting untuk diperhatikan sebagai bagian dari upaya pertumbuhan ekonomi.

Keadilan (fairness) adalah bagaimana hukum menjamin adanya perlindungan, perlakuan yang sama dan adanya standar tingkah laku pemerintah untuk memelihara mekanisme pasar dan pencegahan eksesekses birokratis yang berlebihan. Ketiadaan standar keadilan merupakan masalah terbesar yang dihadapi negara-negara berkembang. Dalam kurun waktu yang lama, hal tersebut bisa menjadi penyebab utama hilangnya legitimasi pemerintah

Pendidikan berkaitan erat dengan pemberian tujuan, yaitu kemampuan hukum sebagai suatu kekuatan pembentuk kebiasaankebiasaan (habits) yang dapat memperkuat kebiasaan lama atau meciptakan respon baru dan kondisi-kondisi tertentu. Di Indonesia, hukum (undangundang) belum dapat sepenuhnya berfungsi pendidikan, atau melakukan fungsi social change. Yang diharapkan di Indonesia adalah bagaimana hukum dapat mendisiplinkan masyarakat dan menciptakan lingkungan usaha yang sehat. 


\section{c. Politik Hukum dan Jatuh Bangun Menuju UU Jaminan Produk Halal}

Menurut Moh. Mahfud MD, politik hukum adalah legal policy yang dilaksanakan secara nasional oleh Pemerintah Indonesia dan meliputi: pertama, pembangunan hukum yang berintikan pembuatan dan pembaruan terhadap materi-materi hukum agar dapat sesuai dengan kebutuhan; kedua, pelaksanaan ketentuan hukum yang telah ada termasuk penegasan fungsi-fungsi lembaga dan pembinaan para penegak hukum (Prof. Mahfudh MD, 1993: 26).

Berangkat dari penjelasan di atas politik hukum mencakup proses pembuatan dan pelaksanaan hukum yang dapat menunjukkan sifat dan ke arah mana hukum akan dibangun dan ditegakkan. Politik hukum adalah arahan atau garis resmi yang dijadikan dasar pijak dan cara untuk membuat dan melaksanakan hukum dalam rangka mencapai tujuan bangsa dan negara. Politik hukum merupakan upaya menjadikan hukum sebagai proses pencapaian tujuan negara. Pijakan utama politik hukum nasional adalah tujuan negara yang kemudian melahirkan sistem hukum nasional yang harus dibangun dengan pilihan isi dan cara-cara tertentu, antara lain memagari hukum dengan program legislasi nasional (Prolegnas).

Secara yuridis, diundangkannya UU Jaminan Produk Halal memiliki dasar yang sangat kuat. Ketentuan Pasal 29 ayat (1) yang dengan tegas menyatakan bahwa Negara berdasar atas Ketuhanan Yang Maha Esa, pada dasarnya mengandung tiga makna, yaitu: Pertama, Negara tidak boleh membuat peraturan perundang-undangan atau melakukan kebijakankebijakan yang bertentangan dengan dasar keimanan kepada Tuhan Yang Maha Esa; Kedua, Negara berkewajiban membuat peraturan perundangundangan atau melakukan kebijakan-kebijakan bagi pelaksanaan wujud rasa keimanan kepada Tuhan Yang Maha Esa dari segolongan pemeluk agama yang memerlukannya; Ketiga, Negara berkewajiban membuat peraturan perundang-undangan yang melarang siapa pun melakukan pelecehan terhadap ajaran agama (paham ateisme).

Selanjutnya Pasal 29 ayat (2) UUD 1945 disebutkan bahwa negara menjamin kemerdekaan tiap-tiap penduduk untuk memeluk agamanya masing-masing dan untuk beribadat menurut agama dan kepercayaannya itu. Terminologi "menjamin" sebagaimana termaktub dalam ayat (2) pasal 
29 UUD 1945 tersebut bersifat "imperatif”. Artinya negara berkewajiban secara aktif melakukan upaya-upaya agar tiap-tiap penduduk dapat memeluk agama dan beribadat menurut agama dan kepercayaannya itu. Pasal tersebut menjadi spirit wujudnya Undang-Undang Jaminan Produk Halal.

Sebenarnya, melalui ketentuan pasal 29 ayat (2) UUD 1945, seluruh syariat Islam, khususnya yang menyangkut bidang-bidang hukum muamalat, pada dasarnya dapat dijalankan secara sah dan formal oleh kaum muslimin, baik secara langsung maupun tidak langsung, dengan jalan diadopsi dalam hukum positif nasional. Politik hukum yang mengakomodir pembentukan peraturan perundang-undangan di Indonesia termuat di dalam Program Legislasi Nasional (Prolegnas). Prolegnas menjadi penting karena menjadi dasar dan awal bagi pembentukan undang-undang yang hendak dibuat (UU No. 10 Tahun 2004).

Selain itu, untuk membangun kepastian hukum yang lebih mantap di bidang Jaminan Produk Halal, maka Prolegnas perlu mendukung legislasi nasional dengan mengagendakan dan memberikan prioritas perundang-undangan yang berkaitan dengan Jaminan Produk Halal.

Penyusunan RUU-RUU tersebut dapat diprakarsai oleh DPR maupun pemerintah sesuai dengan prosedur dan mekanisme yang berlaku.

Secara filosofis, Undang-Undang Jaminan Produk Halal dibentuk dan dikembangkan untuk memenuhi tuntutan penegakan hukum dan keadilan yang merupakan perwujudan dari pelaksanaan hukum Islam, guna menata kehidupan konsumen muslim di Indonesia (Prof. Dr. Muhammad, MM, 2013). Secara yuridis, ia merupakan suprastruktur politik dalam kehidupan berbangsa dan bernegara. Secara historis, ia merupakan keinginan lama yang tertunda bertahun-tahun oleh karena berbagai kasus telah menimpa konsumen, khususnya konsumen muslim. Dan secara sosiologis, ia lahir atas dukungan dan upaya masyarakat, terutama umat Islam dan para ulama, yang merupakan bagian dari intensitas amaliah umat beragama dalam kehidupan masyarakat Indonesia yang sangat plural.

Penegakan hukum adalah sebuah keharusan, penegakan hukum tidak terlepas dari 2 komponen yaitu hukum formil dan hukum materil. Penegakan hukum berarti penegakan hukum formil (hukum acara) dan hukum materil. Pelaksanaan hukum formil dan materil tidak dapat 
dipisahkan, artinya untuk menegakkan hukum materil diperlukan hukum formil. Hukum formil adalah alat (instrumen) untuk menegakkan atau mempertahankan hukum materil. Tanpa hukum formil, hukum materil tidak dapat ditegakkan atau dipertahankan. Karena hukum formil (hukum acara) adalah kumpulan asas dan akidah mengenai tata cara menegakkan atau mempertahankan hukum materil.

\section{Efektifitas Membumikan Hukum Jaminan Produk Halal}

Diskursus hukum Undang-Undang Jaminan Produk Halal dalam konteks ke-Indonesia-an perlu disandingkan dengan kedudukan syariat Islam, fikih dan qanun karena terjadinya perbedaan pandangan di kalangan para ahli mengenai syariat Islam.

Pemahaman kaidah hukum itu pun seyogyanya disertai dengan pendekatan filsafat hukum agar pesan-pesan tersirat (maa wara'a dzalika) yang terdapat dalam Qur'an dan Hadith, sehingga dapat dirumuskan asas dan tujuan dalam suatu kaidah secara utuh (integrated). Apalagi seiring perkembangan sosial masyarakat di berbagai aspeknya kaidah hukum di atas sebaiknya membuka ruang guna mengadopsi adat kebiasaan yang berlaku di suatu daerah, sebagaimana para fuqaha terkadang juga mengadopsi hukum Romawi sehingga terbuktilah fikih hadir dalam sosok hukum yang ramah dan dinamis.

Implementasi hukum Islam (UUD '45) Indonesia sebagai hukum yang hidup (living law) dan berkembang serta ditaati umat Islam di negeri ini tanpa harus mengangkatnya dalam bentuk peraturan perundangundangan. Regulasi hukum tersebut merupakan wujud fungsi negara di bidang memberikan pelayanan produk pangan, obat-obatan dan kosmetika yang bermanfaat bagi rakyatnya. Bukankah falsafah Negara kita adalah tidak adanya asas pemisahan urusan keagamaan dengan urusan kenegaraan (founding fathers negara: Soekarno, Soepomo \& Moh. Yamin).

Undang-Undang Jaminan Produk Halal merupakan upaya untuk mentransformasikan kaidah-kaidah hukum Islam, sebagai hukum yang hidup (living law) di dalam masyarakat menjadi hukum positif. Ruang gerak hukum Undang-undang ini bidang-bidang hukum mengenai produk pangan (makanan dan minuman), obat-obatan, dan kosmetika dimana 
subyek hukum dari hukum positif ini mengikat seluruh warga negara, produsen dan konsumen.

Jika dikelompokkan, pendapat mengenai pentingnya regulasi Undang-Undang Jaminan Produk Halal menjadi sebuah legislasi atau tidak, maka dapat dibagi menjadi dua kelompok, yakni : Kelompok Literalis, yang menegaskan tidak ada kompromi dalam melaksanakan nash syar'iat yang tegas, sehingga harus diwujudkan dalam bentuk UU Jaminan Produk Halal yang bersifat mandatory; dan Kelompok Moderasi, yang berpendapat problematika jaminan produk halal dapat dijadikan dalam bentuk legislasi dan juga boleh dibiarkan apa adanya tidak harus masuk dalam legislasi nasional, yang penting ketika muncul segala problem maka bentuk ancaman hukuman maksimal (ultimum remidium) yang diterapkan berdasarkan tata aturan perundangan meskipun masih bersifat parsial.

Upaya membumikan hukum jaminan produk halal melalui legislasi merupakan suatu "ijtihad" (Al-Syathibi: 53 \& Abu Zahrah:379) menjadikan hukum yang hidup di dalam masyarakat, sebagai sumber hukum bersifat nasional mengenai produk makanan, minuman, obatobatan dan kosmetika.

\section{a. Undang-Undang Jaminan Produk Halal dan Positivisasi Hukum Islam}

Syarian Islam, hukum Islam maupun fikih Islam, adalah hukum yang hidup dalam masyarakat Indonesia. Sementara dalam hal hukum publik, yang syariat Islam itu sendiri hanya memberikan aturan-aturan pokok, atau asas-asasnya saja, maka biarkanlah ia menjadi sumber hukum dalam merumuskan kaidah-kaidah hukum nasional.

Di negara kita, bukan saja hukum Islam - dalam pengertian syariat - yang dijadikan sebagai sumber hukum, tetapi juga hukum adat, hukum eks kolonial Belanda yang sejalan dengan asas keadilan dan sudah diterima masyarakat, tetapi kita juga menjadikan berbagai konvensi internasional sebagai sumber dalam merumuskan kaidah hukum positif kita. Ketika hukum positif itu telah disahkan, maka yang berlaku itu adalah hukum nasional kita, tanpa menyebut lagi sumber hukumnya. Ada beberapa pihak yang mengatakan kalau hukum Islam dijadikan sebagai bagian dari hukum 
nasional, dan syariat dijadikan sumber hukum dalam perumusan kaidah hukum positif, maka Indonesia, katanya akan menjadi negara Islam.

Mengingat hukum Islam itu adalah hukum yang hidup dalam masyarakat Indonesia, maka negara tidak dapat merumuskan kaidah hukum positif yang nyata-nyata bertentangan dengan kesadaran hukum rakyatnya sendiri. Demokrasi harus mempertimbangkan hal ini. Jika sebaliknya, maka negara kita akan menjadi negara otoriter yang memaksakan kehendaknya sendiri kepada rakyatnya.

Implementasi berikutnya mengenai hukum Jamiman Produk Halal tergantung komitmen kita sebagai umat Islam di Indonesia yang telah diberi kebebasan untuk melaksanakan hukum-hukum Allah SWT. terutama hukum keluarga Islam dan ekonomi syariah. Selaku umat Islam baik secara pribadi, kolektif maupun melalui lembaga Islam diharapkan dapat memberikan kontribusinya dalam menopang terlaksananya hukumhukum Allah SWT dengan cara memberikan informasi kepada masyarakat luas tentang jaminan produk halal.

Agustianto menuturkan bahwa berbagai studi tentang hubungan hukum dan pembangunan ekonomi menunjukkan bahwa pembangunan ekonomi tidak akan berhasil tanpa pembaharuan hukum. Memperkuat institusi-institusi hukum adalah "precondition for economic change", "crucial to the viability of new political system", and "an agent of social change". Agar hukum dapat berperan dalam pembangunan ekonomi nasional maka hukum di Indonesia harus memenuhi lima kualitas, yaitu: kepastian (predictability), stabilitas (stability), keadilan (fairness), pendidikan (education), kemampuan SDM di bidang hukum (special abilities of the lawyer).

Itulah sebabnya Munas Alim Ulama MUI memohon pemerintah untuk memantapkan dan lebih mengintensifkan sosialisasi berbagai undang-undang yang terkait kepentingan umat Islam dalam mendukung pelaksanaan ajaran agama kepada masyarakat dan aparatur penyelenggara negara/pemerintah. Hal ini berdasarkan pertimbangan bahwa sampai saat ini masih terdapat warga masyarakat yang belum memahami isi, maksud dan tujuan berbagai Undang-Undang dan masih belum optimalnya pelaksanaan UU oleh aparatur penyelenggara negara/pemerintah yang ditugaskan untuk itu. Khusus mengenai ekonomi syariah, pemerintah 
hendaknya memberikan perhatian lebih besar kepada sistem perekonomian syariah agar lebih berkembang dan memberikan kontribusi lebih besar bagi pertumbuhan ekonomi nasional, kemajuan usaha/bisnis para pengusaha, dan peningkatan pendapatan masyarakat. Hal itu antara lain ditunjukkan dengan menerbitkan berbagai kebijakan dan peraturan (Musyawarah Nasional MUI, 2012).

\section{b. Peran Negara dalam Produk Halal}

Negara memiliki peranan yang strategis dalam pemberlakuan JPH ada beberapa prinsip sebagai pemerintahan yang baik (Mabâdi' alHukûmah al-Fâdhilah), yakni : 1) Kaidah fiqhiyah menegaskan, Tasharruf al-imâm 'ala al-ra'iyyah manûth bi al-mashlahah (kebijakan pemerintah terhadap rakyatnya harus berorientasi kepada kemaslahatan). 2) Dalam memikul tugas kepemimpinan publik, penyelenggara negara khususnya pemerintah harus memenuhi syarat, antara lain : a. Memiliki kemampuan nalar (kecerdasan) untuk menetapkan kebijakan yang menyangkut rakyat dan kemaslahatan mereka (siyâsah al-ra'iyyah wa tadbîr mashâlihihim); b. Memiliki pengetahuan, ketahanan fisik dan mental dengan landasan iman dan taqwa yang membuatnya mampu untuk menyelesaikan berbagai krisis dan menetapkan hukum serta kebijakan secara benar (al-ijtihâd fîalnawâzil wa al-ahkâm). 3) Setiap kebijakan yang diambil oleh pemegang kekuasaan negara, baik eksekutif maupun legislatif dan yudikatif harus didasarkan pada tujuan untuk mewujudkan kemaslahatan rakyat yang bersifat umum serta menghilangkan kemafsadatan dari mereka (iqâmah al-mashâlih wa izâlah al-mafâsid). Dalam implementasinya, mencegah terjadinya kemafsadatan harus didahulukan dari pada upaya mewujudkan kemaslahatan (dar'u al-mafâsid muqaddam 'ala jalbi al-mashâlih̨). 4) Apabila terjadi benturan kepentingan kemaslahatan antara berbagai pihak, maka kepentingan kemaslahatan umum harus didahulukan dari pada kemaslahatan golongan dan perorangan. Demikian juga, ketika terjadi benturan kepentingan kemafsadatan (kerusakan) antara berbagai pihak, maka kemafsadatan yang dialami oleh sekelompok orang bisa diabaikan demi mencegah terjadinya kemafsadatan yang bersifat umum. 5) Pelaksanaan kebijakan penyelenggara negara (tasharruf al-imâm) harus mengedepankan prinsip prioritas (awlawiyyah) sebagai berikut : a. Taqdìm al-ahwaj, yaitu mendahulukan atau memprioritaskan rakyat yang lebih 
membutuhkan dibandingkan dengan pihak yang kurang membutuhkan; $b$. Al-'adlu fî i'thâi $\underline{h} u q u \hat{u} q$ mutasâwî al-ĥhâjât, yaitu membagi secara adil di antara mereka yang memiliki kebutuhan yang sama; c. Mengedepankan sikap amanah dalam mengelola harta kekayaan negara dengan menjauhkan diri dari berbagai praktek pengkhianatan dan korupsi (ghulul).6) Kemaslahatan yang menjadi dasar kebijakan dan tindakan penyelenggara negara harus memenuhi kriteria (dlawâbith) sebagai berikut : a. Kemaslahatan yang dimaksud adalah tercapainya tujuan hukum (maqâshid al-syarîah) yang diwujudkan dalam bentuk terlindunginya lima hak dasar kemanusiaan (aldharûriyyât al-khams), yaitu agama, jiwa, akal, kehormatan/keturunan, dan harta. b. Kemaslahatan yang dibenarkan oleh syari'ah adalah maslahat yang tidak bertentangan dengan nash. c. Kemaslahatan yang dapat dijadikan landasan hukum adalah kemaslahatan yang yang hakiki (benar-benar mendatangkan manfaat dan menolak mudarat). d. Kemaslahatan yang dijadikan landasan hukum harus bersifat pasti (qâthi'ah), terbukti dalam kenyataan (muhaqqaqah), umum, berkelanjutan dan jangka panjang, bukan bersifat spekulatif (mawhûmah), individual, dan sesaat. e. Kemaslahatan yang bersifat umum harus diprioritaskan untuk direalisasikan, meskipun harus mengenyampingkan kemaslahatan yang bersifat individual ataupun kelompok (al-mashlahah al-âmmah muqaddamah 'alâ al-mashlahah alkhâshshah), f. Dalam merealisasikan kemaslahatan, penyelenggara negara dapat menetapkan kebijakan yang berpotensi menimbulkan kerugian bagi perorangan atau sekelompok orang, hanya apabila hal itu benarbenar demi kemaslahatan umum atau untuk mencegah kerugian yang lebih besar. 7) Penyelenggara negara sebagai pengemban amanah untuk mengelola urusan publik harus mendahulukan kepentingan yang bersifat umum dan menjaga kemaslahatan masyarakat banyak, di atas kepentingan perorangan dan golongan. 8) Penyelenggara negara yang tidak mematuhi prinsip-prinsip kemaslahatan sebagaimana disebutkan di atas, berarti telah mengkhianati amanah, dan harus mempertanggungjawabkan secara etik, moral, dan hukum. Dengan demikian, penyelenggara negara semacam itu tidak termasuk dalam kategori pemerintahan yang baik (good governance) siyâsah al-hukûmah al-fâdhilah). 


\section{c. Wajah Hukum Produk Halal : Perspektif Social Angineering}

Ikhtiar menggunakan hukum sebagai sarana rekayasa sosial dengan mengeluarkan berbagai peraturan perundang-undangan tanpa dasar berpijak pada nilai-nilai yang dapat disarikan atau diambil dari berbagai putusan hakim yang telah mempunyai kekuatan hukum tetap dan bernilai sebagai jurizprudensi yang merupakan wadah/wahana yang menampung perkembangan nilai-nilai yang ada di masyarakat merupakan tindakan yang sembrono dan tak dapat dipertanggungjawabkan. Selain itu, penggunaan hukum sebagai sarana rekayasa sosial hanya mungkin dapat dilakukan apabila potensi untuk berkembangnya hukum kebiasaan, adatistiadat, hukum adat sebagai instrumen yang terdapat dalam masyarakat yang memiliki kemampuan untuk mengatur dirinya sendiri, diberi ruang tumbuh dalam sistem hukum nasional (Firman Muntaqo, 2005).

Nampaknya gagasan di atas menunjukkan adanya keinginan untuk menempatkan hukum negara (hukum tertulis) sebagai satu-satunya instrumen yang memadai untuk mengantarkan masyarakat Indonesia menuju kemajuan. Hal ini menunjukkan bahwa, aliran Positivisme Hukum dalam strategi pembangunan hukum di Indonesia, yang pada intinya hendak menyatakan bahwa, masyarakat Indonesia yang maju akan dapat tercipta apabila pemerintah/negara menciptakan dan menggunakan hukum tertulis sebagai sarana untuk mengakomodir perubahan-perubahan yang terjadi pada masyarakat.

Jika aliran positivisme hukum menyatakan bahwa hukum itu diciptakan dan dapat digunakan sebagai alat/instrumen rekayasa sosial (law as a tool of social enginering) untuk mendorong dan menciptakan perubahan dalam masyarakat, maka aliran sejarah berpendapat bahwa hukum bukan diciptakan, namun ditemukan dalam masyarakat. Apabila ditelusuri lebih lanjut, penerapan konsep hukum sebagai alat/instrumen rekayasa sosial dengan menempatkan hukum tertulis yang dibuat atas dasar aliran hukum positivistis bertentangan dengan politik hukum yang diletakkan oleh Founding Fathers yang menempatkan hukum adat sebagai sumber utama pembentukan hukum nasional, atas dasar Sila Persatuan dan Semboyan Bhinneka Tunggal Ika yang mencerminkan adanya pluralisme hukum di Indonesia, namun tetap dalam bingkai persatuan. 
Hukum Jaminan Produk Halal menuntut adanya kepercayaan bahwa pada satuan-satuan masyarakat di Indonesia terdapat modal sosial dan basis sosial yang mampu menjadi alat/sarana penyelenggaraan kehidupan berhukum sekaligus berbangsa dan bernegara, karena dalam satuan-satuan masyarakat tersebut selalu tumbuh dan berkembang The Living Law. Cara berhukum yang harus dilaksanakan di Indonesia sebagai negeri yang pluralis adalah dengan memfasilitasi tumbuh dan berkembangnya The Living Law pada masyarakat dan mensinergikannya dengan kepentingan nasional melalui upaya yang dikenal dengan harmonisasi hukum dan harmonisasi kehidupan sosial.

Sesungguhnya masih ada cara berhukum yang secara sadar dapat mengantarkan suatu masyarakat menjadi modern dan pemberlakuan hukumnya tanpa paksaan karena hukum yang dipaksakan berlaku bertentangan dengan peculiar form of social life dari masyarakat yang bersangkutan. Kondisi demikian lebih dikenal dengan istilah "Law of non tranferability of law" (Robert B.Seidman, 1998: 123).

Undang-Undang Jaminan Produk Halal merupakan gagasan menggeser paradigma yang mendasar dalam cara negara/pemerintah berhukum, yaitu dari cara berhukum yang semula non-positivis dan pluralis menjadi cara berhukum atas dasar faham positivis dan sentralistis. Hal ini jelas nampak dari politik hukum yang mengutamakan keinginan untuk melakukan kodifikasi dan unifikasi hukum nasional yang pada dasarnya merupakan implementasi dari ajaran atau mazhab positivisme hukum.

Upaya untuk menuju masyarakat Indonesia modern dengan hukum modern yang bersumber pada nilai-nilai hukum Indonesia tidak dilaksanakan, bahkan hukum adat terus diupayakan tunduk pada faham/ajaran hukum dari mazhab positivisme hukum. Pada negara yang berkarakter pluralis, seperti halnya Indonesia, maka fungsi hukum Jaminan Produk Halal pada dasarnya adalah mengupayakan adanya harmonisasi hukum, bukan dominasi hukum nasional atas hukum yang hidup pada masyarakat atau The Living Law.

Membumikan Undang-Undang Jaminan Produk Halal dengan memberdayakan hukum sebagai alat rekayasa sosial dalam tulisan ini dipandang efektif, oleh karena mampu menanggalkan ego-sektoral antara indivdu dengan masyarakat umum, antara das sain dan das sollen, antara 
kapitalisme dan islamisme, antara dhahir dan batin, antara masa kini dan mendatang, antara vertikal dan horizontal. Karena secara teoritis, penerapan konsep law as a tool of social engineering dimungkinkan di Indonesia dimana secara sosiologis perkembangan hukum di Indonesia lebih dekat pada faham hukum Civil Law System yang bersifat positivistis, sehingga hukum/law dimaknakan sebagai Act yang harus dipatuhi oleh rakyat, karena dibuat oleh pemegang kedaulatan.

Implementasi konsep law as tool of social engineering diharapkan nilai-nilai yang terkandung dalam berbagai peraturan perundang-undangan tersebut diangkat berdasarkan nilai-nilai yang tumbuh dan berkembang dalam masyarakat Indonesia yang pluralis. Penerapan konsep law as tool of social engineering secara teoritis dimungkinkan, sepanjang hukum Jaminan Produk Halal lebih dimaknakan sebagai Judge Made Law. (Sabian Utsman, 2010: 54)

Arah kebijakan pembentukan peraturan perundang-undangan sesuai dengan TAP MPR Nomor IV/MPR/1999 adalah (1) Menata sistem hukum nasional yang menyeluruh dan terpadu dengan mengakui dan menghormati hukum agama dan hukum adat serta memperbarui perundang-undangan warisan kolonial dan hukum nasional yang diskriminatif, termasuk ketidakadilan gender dan ketidaksesuaiannya dengan tuntutan reformasi melalui program legislasi; (2) Melanjutkan ratifikasi konvensi internasional, terutama yang berkaitan dengan hak asasi manusia sesuai dengan kebutuhan dan kepentingan bangsa dalam bentuk undang-undang; (3) Mengembangkan peraturan perundangundangan yang mendukung kegiatan perekonomian dalam menghadapi era perdagangan bebas tanpa merugikan kepentingan nasional (TAP MPR Nomor IV/MPR/1999).

Permasalahan lain yang dihadapi di bidang pembentukan perundang-undangan, khususnya dalam rangka mendukung pemulihan ekonomi, antara lain adalah masih belum memadainya peraturan perundang-undangan di bidang ekonomi yang secara terus menerus mengalami perubahan sebagai implikasi dari globalisasi dunia. Tidak secara cepatnya perundang-undangan nasional merespon perkembangan yang ada mengakibatkan terjadinya ketidakpastian dan jaminan hukum terhadap implementasi peraturan perundang-undangan terutama di bidang 
ekonomi, sehingga mengakibatkan berkurangnya kepercayaan kalangan dunia usaha terutama para investor dari luar negeri untuk menanamkan modalnya di Indonesia.

Tindak lanjut yang diperlukan untuk meningkatkan peran pembentukan Undang-Undang Jaminan Produk Halal adalah dengan melanjutkan langkah-langkah evaluasi terhadap berbagai peraturan perundang-undangan yang telah dikeluarkan melalui pengkajian yang intensif. Hasil evaluasi harus ditujukan untuk melihat sampai sejauh mana implikasi (impact) dikeluarkannya peraturan perundangan tersebut kepada masyarakat. Apakah dapat menciptakan ketertiban, kepastian dan rasa keadilan masyarakat. Dengan dilakukannya evaluasi yang mendalam maka penyempurnaan dan perubahan peraturan perundang-undangan akan benar-benar sesuai dengan situasi dan kondisi dalam masyarakat.

\section{d. Budaya Hukum sebagai Upaya membumikan UU Jaminan Produk Halal}

Program Peningkatan Kesadaran Hukum dan Pengembangan Budaya Hukum bertujuan untuk meningkatkan kesadaran dan kepatuhan hukum baik masyarakat maupun aparat penyelenggara negara secara keseluruhan dan meningkatkan kepercayaan masyarakat terhadap peran dan fungsi aparat penegak hukum, serta diharapkan akan menciptakan budaya hukum di semua lapisan masyarakat. Adapun sasaran program ini adalah meningkatnya jumlah masyarakat dan aparat penyelenggara negara yang sadar terhadap hak dan kewajibannya serta semakin meningkatnya partisipasi masyarakat dalam berbagai proses perumusan kebijakan pembangunan. Sedangkan arah kebijakan peningkatan Kesadaran Hukum dan Pengembangan Budaya Hukum adalah (1) mengembangkan budaya hukum di semua lapisan masyarakat untuk terciptanya kesadaran dan kepatuhan hukum dalam kerangka supremasi hukum dan tegaknya negara hukum; dan (2) meningkatkan pemahaman dan penyadaran, serta meningkatkan perlindungan, penghormatan, dan penegakan HAM dalam seluruh aspek kehidupan.

Pelaksanaan Program Peningkatan Kesadaran Hukum dan Pengembangan Budaya Hukum selama kurun waktu pelaksanaan Propenas antara lain melalui kegiatan (1) pemetaan permasalahan hukum dalam rangka menerapkan materi, metode, dan pendekatan dialogis 
yang tepat sasaran; (2) menggunakan nilai-nilai budaya luhur daerah sebagai salah satu sarana untuk meningkatkan penyadaran hukum; (3) merumuskan pendekatan penyadaran hukum yang lebih demokratis melalui pendekatan dialogis antara instansi/lembaga pemerintah dan lembaga kemasyarakatan yang memfasilitasi penyadaran hukum dengan masyarakat untuk mengembangkan kesadaran dan peran serta mereka terhadap hukum dan sistem penegakannya; (4) meningkatkan kesadaran masyarakat dalam mengaktualisasikan hak serta melaksanakan kewajiban masyarakat sebagai warga negara sekaligus dalam rangka membentuk budaya hukum bagi masyarakat dan aparat penyelenggara negara; serta (5) meningkatkan penggunaan media komunikasi yang lebih modern dalam rangka pencapaian sasaran penyadaran hukum di berbagai lapisan masyarakat (http://www.hukumonline.com, 2014).

Beberapa problematika yang dihadapi dalam upaya membimikan Hukum Jaminan Produk Halal tersebut antara lain : Pertama, Jumlah pendudukan yang menempati peringkat 4 (empat) di dunia, maka tidak mudah untuk secara serentak melakukan upaya-upaya peningkatan kesadaran hukum dan pengembangan budaya hukum; Kedua, tingkat pendidikan yang masih rendah menjadi salah satu kendala rendahnya kesadaran hukum masyarakat; Ketiga, kelemahan dari program-program Pemerintah dalam menyusun metode peningkatan kesadaran hukum yang dapat langsung dengan mudah dipahami oleh masyarakat yang tingkat pendidikannya bervariasi (http://www.hukumonline.com, 2014).

Upaya membangun paradigma baru pembangunan hukum nasional di bidang produk halal, yakni paradigma pembangunan hukum di Indonesia membutuhkan perumusan yang ekstra hati-hati karena membutuhkan kajian yang komprehensif, baik dilihat dari sisi sektor, bentuk, dan sasaran pembangunan hukum tersebut. Selain harus memperhatikan sisi dinamikanya, heterogenitas yang terkandung dalam komponen-komponen pendukung sistem hukum nasional pun wajib diberi tempat secara tepat dan proporsional dalam perumusan paradigma pembangunan hukum tersebut (http://www.komisihukum.go.id, 2014).

Undang-Undang Jaminan Produk Halal sebagai hukum memang dapat difungsikan sebagai sarana untuk memperbarui masyarakat (social engineering). Namun, perekayasaan sosial seperti itu membutuhkan 
dukungan penelitian yang mendalam tentang hukum perlindungan konsumen, hukum tentang pangan dan hukum-hukum lain yang hidup di masyarakat (living law) serta tingkat kesiapan masyarakat dalam menyikapi pembaruan yang akan dilakukan melalui sarana hukum itu.

\section{Simpulan}

1. Undang-Undang Jaminan Produk Halal adalah payung hukum di bidang produk pangan, obat-obatan dan kosmetika yang digagas sejak lama dan berkali-kali tertunda. Keberadaannya lahir karena kekosongan hukum dan kalaupun ada hukum berkait dengan produk halal, sifatnya masih parsial dan voluntir.

2. Hukum jaminan produk halal kehilangan sifat progresifitasnya.

3. Undang-Undang Jaminan Produk Halal termasuk hukum progresif yang menempatkan manusia sebagai obyek utama. Keberadaannya memberikan peluang terhadap peran masyarakat dalam melakukan sosialisasi, dan edukasi. Upaya penyelarasan keadilan berdasarkan moralitas dan budaya hukum di satu pihak dengan keadilan hukum dilakukan secara berimbang. Terpenuhinya 3 (tiga) komponen hukum, yakni : struktur, substansi dan kultur hukum.

4. Efektifitas membumikan hukum jaminan produk halal pasca disahkan Undang-Undang Jaminan Produk Halal.

5. Hukum jaminan produk halal melalui legislasi merupakan suatu "ijtihad" menjadikan hukum yang hidup di dalam masyarakat, sebagai sumber hukum bersifat nasional mengenai produk makanan, minuman, obat-obatan dan kosmetika. Sedangkan upaya membumikannya melalui berbagai model, seperti : mensosialisasikan kepada para pihak, melakukan penegakan hukum, menciptakan halal sebagai budaya hidup, dan lain-lain. 


\section{BIBLIOGRAFI}

Ali, Chidir, Responsi Hukum Acara Perdata, Bandung: Armico, 1987 al-Asyhar, Thobieb, Bahaya Makanan Haram Bagi Kesehatan Jasmani dan Kesucian Rohani, Jakarta : Al-Mawardi Prima, 2003, hlm.15. Attmasasmita, "Masalah Santunan Terhadap Korban Tindak Pidana", dalam Jurnal Badan Pembinaan Hukum Nasional, Jakarta : Departemen Kehakiman, 1994.

Azizy, Qodri, Menggagas Ilmu Hukum Indonesia, dalam Ahmad Gunawan,

BS, et.al, Menggagas Hukum Progresif Indonesia, Yogyakarta: Pustaka Pelajar, 2006

Djohansjah, J, Legal Justice, Moral Justice dan Social Justice dalam

Penyelesaian Perkara Tindak Pidana Korupsi, dalam Pedoman

Perilaku Hakim, Kode Etik Hakim dan Makalah Berkaitan, Jakarta:

Mahkamah Agung, 2006

Harahap, M. Yahya, Hukum Acara Perdata Tentang Gugatan, Persidangan,

Penyitaan, Pembuktian, dan Putusan Pengadilan, (Jakarta: Sinar Grafika, 2006)

http://www.hukumonline.com/uu-jaminan-produk-halal-berikankepastian-hukum-bagi-konsumen pada 12 Oktober 2014.

http://www.komisihukum.go.id.menuju-paradigma-baru-pembangunanhukum-nasional diakses pada 3 September 2014

Ka'bah Rifyal, Legal Justice, Moral Justice dan Social Justice, dalam

Pedoman Perilaku Hakim, Kode Etik Hakim dan Makalah Berkaitan, Jakarta: Mahkamah Agung, 2006

Kusuma Atmaja, Mochtar, dalam Soetandyo Wignjosoebroto, "Dari Hukum Kolonial Ke Hukum Nasional: Dinamika Sosial Politik dan Perkembangan Hukum di Indonesia", Jakarta, Rajawali Press, 1994. Manan, Abdul, Penerapa Hukum Acara Perdata di Lingkungan Peradilan Agama, Jakarta: Prenada Media, 2005.

Mertokusumo, Sudikno, Hukum Acara Perdata Indonesia, Yogyakarta: Liberty, 1993. 
Muntaqo, Firman, Hukum Sebagai Alat Rekayasa Sosial, makalah diskusi kelas pada Program Doktor Ilmu Hukum UNDIP Semarang, 2005.

Rahardjo, Satjipto, Hukum Progresif Sebagai Dasar Pembangunan Ilmu Hukum Indonesia, dalam Ahmad Gunawan, BS, et.al, Menggagas

Hukum Progresif Indonesia, Yogyakarta: Pustaka Pelajar, 2006 -, Ilmu Hukum, Alumni, Bandung, 1986

-, Risalah Kuliah Ilmu Hukum pada Program Doktor Ilmu Hukum Undip, Semarang tahun 2004, hlm. 14.

--,Pendidikan Hukum sebagai Pendidikan Manusia : Kaitannya

dengan Profesi Hukum dan Pembangunan Hukum Nasional, Yogyakarta : Genta Publishing, 2009, hlm. 5.

Sabian Utsman, Menuju Penegakan Hukum Responsif : Konsep Philippe

Nonet \& Philip Selznick Perbandingan Civil Law system \& Common

Law System Spiral kekerasan dan Penegakan Hukum, Yogyakarta :

Pustaka Pelajar, 2010.

Seidman, Robert B., dalam Ronny Hanitijo Soemitro, "The Law of Nontransferability of Law Menurut Robert B. Seidman", Badan Penerbit Universitas Diponegoro, Semarang, 1998.

Spence, Gary, The Death of Justice, New York : St. Martin's Press, 1997.

Sutantio, Retnowulan, et.al, Hukum Acara Perdata Dalam Teori dan Praktek, Bandung: Mandar Maju, 2005

Sudjono, HS. Brojo, Reorientasi Pengelolaan Ilmu Hukum dalam Fakultas Hukum Universitas Islam Indonesia, Jurnal Hukum Ius Quia Iustum, Nomor 27, Volume 11 September 2004.

Syamsudin, M., Konstruksi Baru Budaya Hukum Hakim Berbasis Hukum Progreasif, Jakarta : Prenada Media Group, 2012, hlm. 105.

Al-Syathibi dalam Al-Muwafaqat $f i$ Ushul al-Ahkam, Dar al-Baidla : Dar al-Rasyad wa al-Haditsah, jilid II, hlm, 53. Abu Zahrah, Ushul alFiqh, Dar al-Fikr al-Arabi, tt.

Trubek, David. dkk., Global Structuring and The Law : The Internalization of Legal Fields and The Creation of Transnational arenas, 1993.

Warassih, Esmi, Pranata Hukum Sebuah Telaah Sosiologis, dalam Karolus Kopong Medan dan Mahmutarom (ed.), Semarang : Suryandaru Utama, 2005. 